\title{
PENGARUH PENERAPAN MODEL PEMBELAJARAN INTERACTIVE LECTURE DEMONSTRATIONS (ILDS) TERHADAP KEMAMPUAN PEMAHAMAN KONSEP FISIKA SISWA
}

\author{
Petri Reni Sasmita ${ }^{1}$, Halimatus Sakdiah ${ }^{2}$, dan Zainal Hartoyo ${ }^{3}$ \\ petrirenisasmita@gmail.com \\ 1,2Program Studi Pendidikan Fisika, STKIP Muhammadiyah Sungai Penuh, Jambi, Indonesia \\ ${ }^{3}$ Program Studi Tadris Fisika, Fakultas Tarbiyah dan Keguruan, UIN Sulthan Thaha Saifuddin Jambi, Indonesia
}

Received: 28 Mei 2020

Revised: 30 Mei 2020

Accepted: 15 Mei 2020

\begin{abstract}
This study aims to determine the effect of Interactive Lecture Demonstrations (ILDs) learning models on students' understanding of physics concepts. The research method used was a preliminary experimental research method with a one-group pretest-posttest design that was carried out in class XI students in one of the high schools (SMA) in Kerinci Regency. The sampling technique uses a cluster sampling method. Data collection uses a pre-test and a post-test to measure students' understanding of physics concepts. The results of the calculation of the effect size indicate that the application of learning with Interactive Lecture Demonstrations (ILDs) models has a major effect on the ability of understanding students' physics concepts. The effect size calculation in this study was carried out using the Cohen formula. From the calculation results obtained effect size score of 0.81 . This score is in the big category. This shows that the application of the Interactive Lecture Demonstrations (ILDs) learning model has a big influence on students' conceptual understanding ability. Thus, it can be concluded that the application of Interactive Lecture Demonstrations (ILDs) models in learning physics has a great influence on the ability of understanding students' physics concepts.
\end{abstract}

\begin{abstract}
Abstrak:Penelitian ini bertujuan untuk mengetahui pengaruh model pembelajaran Interactive Lecture Demonstrations (ILDs) terhadap kemampuan pemahaman konsep fisika siswa. Metode penelitian yang digunakan adalah metode penelitian eksperimen awal dengan desain one-group pretest-posttest design yang dilaksanakan pada siswa kelas XI di salah satu sekolah menengah atas (SMA) di Kabupaten Kerinci. Teknik pengambilan sampling menggunakan metode sampling kelompok (cluster sampling). Pengumpulan data menggunakan tes awal (pretest) dan tes akhir (posttest) untuk mengukur kemampuan pemahaman konsep fisika siswa. Hasil perhitungan effect size menunjukkan bahwa penerapan pembelajaran dengan model Interactive Lecture Demonstrations (ILDs) berpengaruh besar terhadap kemampuan pemahaman konsep fisika siswa. Perhitungan effect size dalam penelitian ini dilakukan dengan menggunakan rumus Cohen. Dari hasil perhitungan tersebut didapat skor effect size sebesar 0,81. Skor ini berada pada kategori besar. Hal ini menunjukkan bahwa penerapan model pembelajaran Interactive Lecture Demonstrations (ILDs) berpengaruh besar terhadap kemampuan pemahaman konsep siswa. Dengan demikian, dapat disimpulkan bahwa penerapan model Interactive Lecture Demonstrations (ILDs) dalam pembelajaran fisika memiliki pengaruh yang besar terhadap kemampuan pemahaman konsep fisika siswa.
\end{abstract}

Kata kunci:Model Interactive Lecture Demonstrations (ILDs), pemahaman konsep fisika.

\section{PENDAHULUAN}

Pendidikan adalah proses untuk memberikan manusia berbagai macam situasi yang bertujuan memberdayakan diri. Perubahan dan perkembangan aspek pendidikan perlu ditunjang oleh 
kinerja pendidikan yang bermutu tinggi. Pendidikan yang berkualitas sangat diperlukan guna mendukung terciptanya sumber daya manusia berkualitas serta mampu bersaing di era globalisasi. Pendidikan memegang peranan yang sangat penting dalam proses peningkatan kualitas sumberdaya manusia (Novitasari, S, 2019).

Ilmu pengetahuan alam (IPA) pada hakikatnya tidak hanya terdiri atas kumpulan pengetahuan saja, tetapi juga merupakan proses aktif menggunakan keterampilan untuk mempelajari alam, melalui kegiatan ilmiah. sehingga, sebagai salah satu bagian dari IPA penyelenggaraan pembelajaran fisika juga harus sesuai dengan hakikat IPA. Hal itu selajan dengan kurikulum 2013 yang menuntut pelaksanaan pembelajaran fisika diselenggarakan secara interaktif, inspiratif, menyenangkan, menantang, memotivasi siswa untuk berpartisipasi aktif, serta memberikan ruang yang cukup bagi prakarsa, kreativitas, dan kemandirian sesuai dengan bakat, minat, dan perkembangan fisik serta psikologis siswa. Pembelajaran fisika merupakan proses antara guru dan siswa yang melibatkan pengembangan pola berpikir dan mengola logika pada suatu lingkungan belajar yang sengaja diciptakan oleh guru dengan berbagai metode agar program belajar fisika tumbuh dan berkembang secara optimal dan siswa dapat melakukan kegiatan belajar secara efektif dan efesien. Pembelajaran fisika yang diberikan tidak hanya transfer pengetahuan tetapi sesuatu yang harus dipahami oleh peserta didik yang diperlukan dalam kehidupan sehari- hari (Srilisnani, M., Amin, A., \& Yolanda, Y ,2019).

Berdasarkan tujuan yang dirancang pada dokumen kurikulum 2013, maka pembelajaran harus berkenaan dengan kesempatan yang diberikan kepada peserta didik untuk mengkonstruksi pengetahuan dalam proses kognitifnya. Tujuan tersebut juga menjelaskan bahwa siswa harus dapat menguasai konsep fisika. Salah satu kemampuan kognitif yang harus dimiliki oleh siswa untuk dapat menguasai konsep fisika adalah kemampuan memahami. Siswa diharapkan dapat memahami materi ajar dengan baik dan secara utuh setelah mengikuti pembelajaran fisika (Patriot, E. A, 2019). Fisika merupakan ilmu yang mempelajari tentang fenomena gejala alam dan tak lepas dari penerapan kehidupan seharihari. Fisika juga merupakan ilmu universal yang mendasari perkembangan teknologi modern dan mempunyai peran penting dalam berbagai disiplin ilmu dan mengembangkan daya pikir manusia. Untuk menguasai dan meciptakan teknologi dimasa depan diperlukan penguasaan konsep-konsep Fisika sejak dini dan dilakukan suatu tindakan yang terencana. Oleh karena itu, Fisika berperan mempersiapkan siswa atau generasi penerus agar dapat menghadapi tantangan-tantangan di kehidupan yang semakin berkembang dan modern. Persiapan- 
persiapan yang tersebut dilakukan dengan membekali siswa kemampuan berpikir logis, mengembangkan, pemahaman konsep, sistematis, mandiri, dan kreatif (Ariani, T., \& Yolanda, Y, 2019).

Hasil observasi pada salah satu sekolah menengah atas (SMA) di Kabupaten Kerinci menunjukkan bahwa ada 5 permasalahan dalam pembelajaran fisika di kelas. Permasalahan pembelajaran fisika tersebut meliputi: (1) pembelajaran fisika masih sangat bersifat matematis sehingga konsep fisika terabaikan; (2) siswa tidak dilatih untuk menghubungkan konsep dengan fenomena alam dalam kehidupan sehari-hari; (3) pertanyaan dalam pembelajaran fisika yang diajukan guru kepada siswa menuntut siswa untuk mengingat bukan memahami; (4) jawaban siswa atas pertanyaan guru masih bersifat hafalan; (5) kemampuan pemahanan konsep siswa secara rata-rata masih rendah. Pembelajaran yang sering dilakukan adalah pembelajaran dengan metode ceramah serta siswa hanya dibiasakan untuk melakukan penyelesaian soal dengan menggunakan rumus-rumus fisika dan jarang melakukan penanaman konsep secara mendalam terlebih dahulu. Efek dari pembelajaran yang cenderung seperti itu tidak jarang mengakibatkan siswa tidak mampu memahami konsep secara utuh bahkan dapat mengalami miskonsepsi.

Lebih lanjut, data dari Kementerian Pendidikan dan Kebudayaan menunjukkan bahwa rata-rata hasil Ujian Nasional Berbasis Komputer (UNBK) siswa pada Sekolah Menengah Atas (SMA) di kabupaten Kerinci dalam mata pelajaran fisika berada jauh di bawah rata-rata UNBK provinsi Jambi (Kemendikbud, 2019). Rata-rata UNBK mata pelajaran fisika peserta didik di kabupaten Kerinci adalah 35,67 dengan rata-rata UNBK provinsi Jambi 49,34 (Kemendikbud, 2019). Rendahnya rata-rata UNBK tersebut sangat erat hubungannya dengan rendahnya kemampuan pemahaman konsep fisika siswa.

Mengingat besarnya peranan kemampuan pemahaman kosep dalam menentukan keberhasilan siswa dalam belajar fisika, maka kajian mengenai penerapan model pembelajaran yang berpengaruh terhadap kemampuan pemahaman kosep fisika merupakan sesuatu yang sangat penting untuk dilakukan. Hal ini dilakukan supaya tercipta pembelajaran yang dapat meningkatkan pemahaman kosep fisika siswa. Oleh karena itu, penelitian ini difokuskan pada mengkaji pengaruh penerapan model pembelajaran Interactive Lecture Demonstrations (ILDs) terhadap kemampuan pemahaman konsep fisika siswa.

\section{LANDASAN TEORI}

\section{Interactive Lecture Demonstrations (ILDs)}


Interactive Lecture Demonstrations (ILDs) merupakan suatu model pembelajaran yang berpusat pada siswa dan bertujuan untuk mengasah kemampuan pemahaman konsep siswa dalam suatu pembelajaran (Sokoloff \& Thornton, 2006). Model pembelajaran Interactive Lecture Demonstrations (ILDs) (Sokoloff \& Thornton, 2006) ini memiliki delapan langkah yaitu:

1. Guru mendeskripsikan demonstrasi dan melakukan demonstrasi tersebut dengan menghentikan bagian yang akan diprediksi di depan kelas. Demonstrasi dilakukan tanpa ada pengumpulan data.

2. Siswa diminta untuk mencatat prediksi secara individu pada kertas prediksi. Kemudian kertas tersebut dikumpulkan.

3. Siswa terlibat dalam diskusi kelompok kecil. Kelompok ini terdiri atas dua atau tiga orang.

4. Guru memunculkan prediksi siswa pada diskusi kelas

5. Siswa menuliskan prediksi akhir setelah didiskusikan dalam kelas besar oleh guru bersama siswa

6. Guru melakukan demonstrasi dengan menampilkan hasil pengumpulan data pengamatan

7. Siswa mendeskripsikan hasil pengamatan dan mendiskusikannya dengan mengaitkkan hasil pengamatan dengan demonstrasi. Siswa mengisi lembar hasil yang nantinya akan menjadi bahan belajar mereka

8. Siswa bersama guru mendiskusikan suatu permasalahan baru namun masih menggunakan konsep yang sama.

Langkah-langkah model pembelajaran Interactive Lecture Demonstrations (ILDs) yang dikemukakan oleh Sokoloff dan Thornton tersebut kemudian dijadikan tiga langkah saja (Crouch, Fagen, Callan, \& Mazur, 2004). Ketiga langkah tersebut adalah prediksi (predict), pengalaman (experience), dan refleksi(reflect) (Crouch et al., 2004).

\section{Prediksi (Predict)}

Predict dalam model pembelajaran Interactive Lecture Demonstrations (ILDs) diawali dengan guru mendeskripsikan demonstrasi dan melakukan demonstrasi tersebut dengan menghentikan bagian yang akan diprediksi di depan kelas. Kemudian siswa diminta untuk membuat prediksi secara individu, kelompok kecil dan kelompok besar. Prediksi secara individu ditulis dalam lembar prediksi.

2. Pengalaman (Experience) 
Experience dalam model pembelajaran Interactive Lecture Demonstrations (ILDs) merupakan tahap dimana guru melakukan demonstrasi dengan menampilkan hasil pengumpulan data pengamatan. Siswa kemudian berdiskusi untuk mendeskripsikan hasil pengamatan kemudian mengaitkan hasil pengamatan dengan demonstrasi. Demonstrasi dan diskusi yang dilakukan pada tahap experience masih membahas pertanyaan-pertanyaan yang diajukan dalam kegiatan prediksi.

3. Refleksi (Reflect)

Reflect dalam model pembelajaran Interactive Lecture Demonstrations (ILDs) merupakan tahap terakhir di mana guru bersama dengan siswa mendiskusikan suatu permasalahan yang terkait dengan konsep yang telah dipelajari.

\section{Kemampuan Pemahaman Konsep}

Kemampuan pemahaman konsep adalah kemampuan memahami konsep fisika yang menyangkut kemampuan siswa dalam memaknai konsep atau arti fisis dari konsep (Engelhardt \& Beichner, 2004). Indikator proses kognitif yang menyangkut kemampuan pemahaman konsep berdasarkan taxonomi Bloom yang direvisi (Anderson et al., 2001) adalah: (1) menafsirkan (interpreting), (2) mencontohkan (exemplifying), mengklasifikasikan (classifying), (4) meringkas (summarizing), (5) menginferensi (inferring), (6) membandingkan (comparing), dan (7) menjelaskan (explaining).

\section{Menafsirkan (interpreting)}

Menafsirkan terjadi ketika siswa mampu mengubah suatu informasi dari satu bentuk informasi ke bentuk informasi yang lainnya. Kemampuan ini meliputi kemampuan mengubah kata-kata ke grafik atau gambar atau sebaliknya, dari kata-kata ke angka atau sebaliknya, maupun dari kata-kata ke kata-kata lain (Anderson et al., 2001). Kemampuankemampuan dalam proses menafsirkan yakni: (1) menerjemahkan suatu abstraksi menjadi abstraksi dalam bahasa yang lain, (2) menerjemahkan suatu bentuk simbolik ke bentuk simbolik yang lain atau sebaliknya.

2. Mencontohkan (exemplifying)

Proses kognitif mencontohkan terjadi manakala siswa mampu memberikan contoh khusus dari suatu konsep atau prinsip yang bersifat umum (Anderson et al., 2001). Memberikan contoh menuntut kemampuan mengidentifikasi ciri-ciri pokok suatu konsep atau prinsip umum dan selanjutnya menggunakan ciri-ciri tersebut untuk memilih atau membuat contoh.

3. Mengklasifikasikan (classifying) 
Proses kognitif mengklasifikasikan terjadi ketika siswa mengetahui bahwa sesuatu (benda atau fenomena) masuk dalam kategori konsep atau prinsip tertentu (Anderson et al., 2001). Mengklasifikasikan melibatkan proses mendeteksi cici-ciri atau pola-pola yang sesuai dengan contoh tertentu dan konsep atau prinsip tersebut. Termasuk dalam kemampuan mengklasifikasikan adalah mengenali ciri-ciri yang dimiliki suatu benda atau fenomena. Istilah lain untuk mengkalsifikasikan adalah mengkategorisasikan (categorising).

4. Merangkum (summarizing)

Proses kognitif merangkum terjadi ketika siswa mengemukahkan suatu kalimat yang merepresentasikan informasi yang diterima atau mengabstraksi sebuah tema (Anderson et al., 2001). Kemampuan meringkas terbentuk dalam diri siswa ketika siswa mampu membuat suatu pernyataan yang mewakili seluruh informasi. Meringkas menuntut siswa untuk memilih inti dari suatu informasi dan meringkasnya. Istilah lain untuk meringkas adalah menggeneralisasi (generalising) dan mengabstraksi (abstracting).

5. Menyimpulkan (inferring)

Proses kognitif menyimpulkan menyertakan proses menemukan pola dalam sejumlah contoh. Menyimpulkan terjadi ketika siswa dapat mengabstraksi sebuah konsep atau prinsip yang menerangkan contoh-contoh tersebut dengan mencermati ciri-ciri setiap contohnya dan yang terpenting dengan menarik hubungan diantara ciri-ciri tersebut (Anderson et al., 2001). Untuk dapat melakukan penyimpulan siswa harus terlebih dahulu dapat menarik abstraksi suatu konsep/prinsip berdasarkan sejumlah contoh yang ada. Istilah lain untuk menyimpulkan adalah mengekstrapolasi (extrapolating), menginterpolasi (interpolating), memprediksi (predicting), dan menarik kesimpulan (concluding).

6. Membandingkan (comparing)

Proses kognitif membandingkan melibatkan proses mendeteksi persamaan dan perbedaan antara dua atau lebih objek, peristiwa, ide, masalah, atau situasi (Anderson et al., 2001). Membandingkan mencakup juga menemukan kaitan antara unsur-unsur satu objek atau keadaan dengan unsur yang dimiliki objek atau keadaan lain. Istilah lain untuk membandingkan adalah mengkontraskan (contasting), mencocokkan (matching), dan memetakan (mapping).

7. Menjelaskan (explaining)

Proses kognitif menjelaskan berlangsung ketika siswa dapat membuat dan menggunakan model sebab-akibat dalam sebuah sistem (Anderson et al., 2001). Model ini dapat diturunkan dari teori atau didasarkan pada hasil penelitian atau pengalaman. Termasuk 
dalam "menjelaskan" adalah menggunakan model tersebut untuk mengetahui apa yang terjadi apabila salah satu bagian sistem tersebut diubah.

Melalui analisis terkait kecocokan indikator kemampuan pemahaman kosep dengan pembelajaran fisika dengan model Interactive Lecture Demonstrations (ILDs), maka dalam penelitian ini hanya 5 indikator kemampuan pemahaman kosep saja yang digunakan. Ke-lima indikator tersebut adalah menafsirkan, mencontohkan, menginferensi, membandingkan, menjelaskan.

\section{METODOLOGI PENELITIAN}

Penelitian ini adalah penelitian eksperimental dengan metode eksperimen awal dengan desain one-group pretest-posttest design (Fraenkel, J. R., Wallen, N. E., \& Hyun, 2012). Penelitian dilakukan pada siswa kelas XI di salah satu sekolah menengah atas (SMA) di Kabupaten Kerinci. Teknik pengambilan sampling menggunakan metode sampling kelompok (cluster sampling). Pengambilan data dilakukan dengan cara memberikan tes awal (pretest) kepada siswa sebelum pembelajaran dengan model Interactive Lecture Demonstrations (ILDs) dilaksanaan dan setelah pembelajaran dengan model Interactive Lecture Demonstrations (ILDs) dilaksanakan siswa diberikan tes akhir (posttest). Data yang diperoleh kemudian diolah menggunakan perhitungan N-gain (Hake, 2012) dan effect size (Dunst, Hamby, \& Trivette, 2004). Persamaan untuk menghitung N-gain (Hake, 2012)adalah sebagai berikut :

$$
<g>=\frac{\left(\%<S_{f}>-\%<S_{i}>\right)}{\left(100-\%<S_{i}>\right)}
$$

Keterangan:

$\langle g\rangle=$ Skor N-gain

$S_{f} \quad=$ skor tes akhir

$S_{i} \quad=$ skor tes awal

Hasil perhitungan $\mathrm{N}$-gain tersebut kemudian diinterpretasikan kedalam kategori tertentu yang meliputi tinggi, sedang, dan rendah. Pengkategorian skor N-gain (Hake, 2012) ditunjukkan pada Tabel 1 .

Tabel 1.Kategori Skor $N$-Gain

\begin{tabular}{cc}
\hline Kategori N-gain & Kategori \\
\hline $0,70>(<\mathrm{g}>)$ & Tinggi \\
$0,30 \leq(<\mathrm{g}>) \leq 0,70$ & Sedang \\
$(<\mathrm{g}>)<0,30$ & Rendah \\
\hline
\end{tabular}


Persamaan untuk menghitung Effect size (Dunst, Hamby, \& Trivette, 2004)adalahsebagai berikut:

$$
d=\frac{M_{e}-M_{c}}{\sqrt{\frac{S D_{e}{ }^{2}+S D_{c}^{2}}{2}}}
$$

Keterangan:

$d \quad=$ Nilai effect size

$M_{e} \quad=$ Nilai rata-rata tes akhir (posttest)

$M_{c} \quad=$ Nilai rata-rata tes awal (pretest)

$S D_{e} \quad=$ Standar deviasi tes akhir (posttest)

$S D_{c} \quad=$ Standar deviasi tes awal (pretest)

Hasil yang didapatkan dari perhitungan effect size (Dunst, Hamby, \& Trivette, 2004)tersebut kemudian diintepretasikan dengan menggunakan kategori, sebagai berikut.

Tabel 2. Kategori effect size

\begin{tabular}{cc}
\hline Effect size & Kategori \\
\hline$d<0,2$ & Sangat Kecil \\
$0,2 \leq d<0,5$ & Kecil \\
$0,5 \leq d<0,8$ & Sedang \\
$0,8 \leq d<1,0$ & Besar \\
$d \geq 1,0$ & Sangat Besar \\
\hline
\end{tabular}

\section{HASIL DAN PEMBAHASAN}

Rekapitulasi secara umum perolehan rata-rata skor tes awal (pretest) dan tes akhir (posttest) kemampuan pemahaman konsep fisika siswa menunjukkan bahwa peningkatan kemampuan pemahaman konsep siswa cukup tinggi. Hal tersebut ditunjukkan oleh perolehan rerata skor $\mathrm{N}$-Gain sebesar 0,43. Rata-rata skor N-Gain ini berada pada kategori sedang. Hasil rekapitukasi secara lebih rinci ditunjukkan pada Tabel 3.

Tabel 3. Rekapitulasi tes awal (pretest), dan tes akhir (posttest), dan N-Gain kemampuan pemahaman konsep fisika siswa

\begin{tabular}{lcc}
\hline \multirow{2}{*}{ Deskripsi } & \multicolumn{2}{c}{ Tes } \\
\cline { 2 - 3 } & Pretest & Posttest \\
\hline Skor Maksimum & 62,50 & 93,33 \\
Skor Minimum & 16,67 & 43,33 \\
Skor Rata-rata & 43,17 & 61,67 \\
\hline \multicolumn{1}{c}{$N$-gain } & \multicolumn{2}{c}{0,43}
\end{tabular}

Berdasarkan Tabel 3, dapat diketahui bahwa skor minimum tes awal (pretest) dan tes akhir (posttest) memilki perbedaan, dan begitu juga untuk skor maksimul tes awal (pretest) Puplished at https://ojs.stkippgri-lubuklinggau.ac.id/index.php/SJPIF 
dan tes akhir (posttest) juga memiliki perbedaan. Skor maksimum dan minimum tes akhir (posttest) lebih tinggi dari skor maksimum dan minimum tes awal (pretest). Hal ini mengindikasikan bahwa adanya pengaruh penerapan model pembelajaran Interactive Lecture Demonstrations (ILDs) terhadap pemahaman konsep fisika siswa. Selain itu juga, dari Tabel 3 dapat diketahui bahwa kemampuan pemahaman konsep siswa mengalami peningkatan yang cukup tinggi, hal ini terlihat dari $\mathrm{N}$-gain sebesar 0,43 yang berada pada kategori sedang. Ngain yang berada pada kategori sedang ini semakin memperkuat anggapan bahwa adanya pengaruh penerapan model pembelajaran Interactive Lecture Demonstrations (ILDs) terhadap pemahaman konsep fisika siswa.

Perolehan skor pemahaman konsep yang masih bersifat umum tersebut dapat juga dilihat secara khusus dengan cara menguraikan $\mathrm{N}$-gain kemampuan pemahaman konsep berdasarkan setiap indikatornya. Hasil penguraian tersebut menunjukkan bahwa adanya perbedaan N-gain setiap indikator pemahaman konsep siswa, seperti yang tampak pada Gambar 1 .

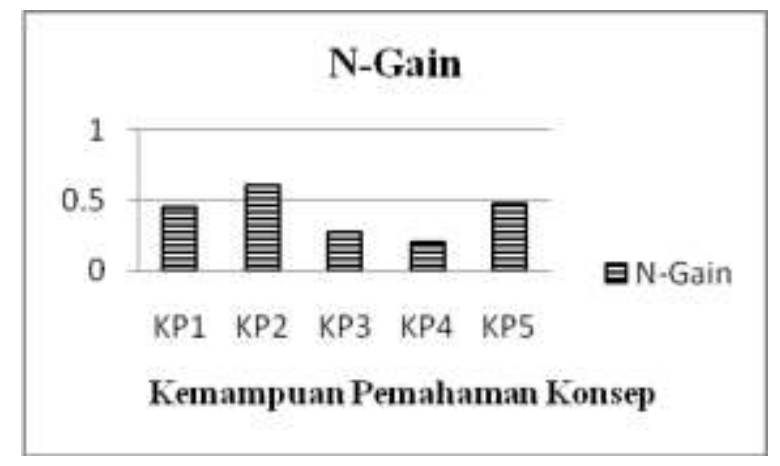

Keterangan gambar: KP1 = Menafsirkan, KP2 = Mencontohkan, KP3 = Menginferensi, KP4 = Membandingkan, KP5 $=$ Menjelaskan

Gambar 1. Hasil penguraian kemampuan pemahaman konsep siswa berdasarkan setiap indikatornya

Melalui Gambar 1 dapat diketahui bahwa capaian tertinggi rerata skor $\mathrm{N}$-gain kemampuan pemahaman konsep siswa terdapat pada indikator mencontohkan yakni sebesar 0,61 , sedangkan capaian terendah terdapat pada indikator membandingkan yakni sebesar 0,2. Jika dilihat berdasarkan kategori N-gainnya, dapat diketahui bahwa untuk indikator menafsirkan, mencontohkan, dan menjelaskan berada pada kategori sedang, sedangkan untuk indikator menginferensi dan membandingkan berada pada kategori rendah. Secara keseluruahan, setiap indikator menunjukan bahwa adanya pengingkatan kemampuan pemahaman konsep fisika siswa, hal ini semakin memperkuat anggapan bahwa adanya pengaruh penerapan model pembelajaran Interactive Lecture Demonstrations (ILDs) terhadap pemahaman konsep fisika siswa. Untuk mengetahui besarnya pengaruh penerapan 
model ini terhadap pemahaman konsep fisika siswa, maka dilakukanlah perhitungan effect size.

Perhitungan effect size dalam penelitian ini dilakukan dengan menggunakan rumus Cohen. Dari hasil perhitungan tersebut didapat skor effect size sebesar 0,81. Skor ini berada pada kategori besar. Hal ini menunjukkan bahwa penerapan model pembelajaran Interactive Lecture Demonstrations (ILDs) berpengaruh besar terhadap kemampuan pemahaman konsep siswa. Sehingga dapat dinyatakan bahwa penerapan model pembelajaran Interactive Lecture Demonstrations (ILDs) sangat berpengaruh terhadap kemampuan pemahaman konsep fisika siswa. Hasil ini bersesuaian dengan hasil penelitian lain mengenai penerapan pembelajaran Interactive Lecture Demonstrations (ILDs) dalam pembelajaran fisika (Sharma et al., 2010). Lebih lanjut, hasil ini juga berseuaian dengan penerapan pembelajaran Interactive Lecture Demonstrations (ILDs) dalam termodinamika (Wattanakasiwich, Khamcharean, Taleab, \& Sharma, 2012)

\section{SIMPULAN DAN SARAN \\ SIMPULAN}

1. Penerapan model pembelajaran Interactive Lecture Demonstrations (ILDs) dapat meningkatkan pemahaman konsep fisika siswa dengan skor $\mathrm{N}$-gain $=0,43$ yang berada pada kategori sedang.

2. Penerapan model pembelajaran Interactive Lecture Demonstrations (ILDs) memiliki pengaruh yang signifikan terhadap pemahaman konsep fisika siswa dengan skor effect size $=0,81$ yang berada pada kategori besar.

\section{SARAN}

Untuk mengetahui lebih jauh mengenai pengaruh model pembelajaran Interactive Lecture Demonstrations (ILDs) terhadap pemahaman konsep fisika siswa, diperlukan kajian yang melibatkan kelas pembelajaran fisika yang lebih banyak bukan hanya satu kelas seperti pada penelitian ini.

\section{DAFTAR PUSTAKA}

Anderson, L. W., Krathwohl Peter W Airasian, D. R., Cruikshank, K. A., Mayer, R. E., Pintrich, P. R., Raths, J., \& Wittrock, M. C. (2001). Taxonomy for_Assessing a Revision OF BlOOM'S TaxONOMy OF EducatiONal Objectives. Retrieved from https://www.uky.edu/ rsand1/china2018/texts/Anderson-Krathwohl - A taxonomy for learning teaching and assessing.pdf 
Ariani, T., \& Yolanda, Y. (2019). Effectiveness of Physics Teaching Material Based on Contextual Static Fluid Material. Kasuari: Physics Education Journal (KPEJ), 2(2), 7081.

Crouch, C., Fagen, A. P., Callan, J. P., \& Mazur, E. (2004). Classroom demonstrations: Learning tools or entertainment? American Journal of Physics, 72(6), 835-838. https://doi.org/10.1119/1.1707018

Dunst, C. J., Hamby, D. W., \& Trivette, C. M. (2004). Guidelines for Calculating Effect Sizes for Practice-Based Research Syntheses. 3(1).

Engelhardt, P. V., \& Beichner, R. J. (2004). Students' understanding of direct current resistive electrical circuits. American Journal of Physics, 72(1), 98-115. https://doi.org/10.1119/1.1614813

Fraenkel, J. R., Wallen, N. E., \& Hyun, H. H. (2012). How to Design and Evaluate Research in Education (8th, Ed.). New York: McGraw-Hill.

Hake, R. R. (2012). Interactive-engagement versus traditional methods: A six-thousandstudent survey of mechanics test data for introductory physics courses Interactiveengagement versus traditional methods: A six-thousand-student survey of mechanics test data for introduc. 64(1998). https://doi.org/10.1119/1.18809

Kemendikbud. (2019). LAPORAN HASIL UJIAN NASIONAL | KEMENTERIAN PENDIDIKAN DAN KEBUDAYAAN. Retrieved August 19, 2019, from https://hasilun.puspendik.kemdikbud.go.id/

Novitasari, S. (2019). EFEKTIVITAS BUKU AJAR BERBASIS HIGHER ORDER THINKING SKILLS (HOTS) PADA MATERI ELASTISITAS DAN HUKUM HOOKE SISWA KELAS XI SMA NEGERI TUGUMULYO TAHUN PELAJARAN 2018/2019. SILAMPARI JURNAL PENDIDIKAN ILMU FISIKA, 1(1), 77-86.

Patriot, E. A. (2019). ANALISIS LEVEL PEMAHAMAN SISWA PADA KONSEP USAHA DAN ENERGI MELALUI PENERAPAN PEMBELAJARAN KONSEPTUAL INTERAKTIF DENGAN PENDEKATAN MULTIREPRESENTASI. JIFP (Jurnal Ilmu Fisika dan Pembelajarannya), 3(1), 34-41.

Sharma, M. D., Johnston, I. D., Johnston, H., Varvell, K., Robertson, G., Hopkins, A., ... Thornton, R. (2010). Use of interactive lecture demonstrations: A ten year study. Physical Review Special Topics - Physics Education Research, 6(2), 1-9. https://doi.org/10.1103/PhysRevSTPER.6.020119

Srilisnani, M., Amin, A., \& Yolanda, Y. (2019). Penerapan Model Pembelajaran Contextual Teaching And Learning (CTL) terhadap Aktivitas Siswa Kelas X di SMA Negeri 5 Model Lubuklinggau Tahun Pelajaran 2018/2019. SILAMPARI JURNAL PENDIDIKAN ILMU FISIKA, 1(1), 60-73.

Sokoloff, D. R., \& Thornton, R. K. (2006). Interactive Lecture Demonstrations Active Learning in Introductory Physics. US: Wiley.

Wattanakasiwich, P., Khamcharean, C., Taleab, P., \& Sharma, M. (2012). Interactive lecture demonstration in thermodynamics. Latin American Journal of Physics Education, 6(4), $508-514$. 